\title{
PERANCANGAN SISTEM INFORMASI PENJUALAN DONAT PADA PT KING ALIANZ DONUTS
}

\author{
Ade Pebrianto ${ }^{1}$, Rahman Abdillah ${ }^{2}$, V.H.Valentino ${ }^{3}$ \\ Program Studi Informatika, Fakultas Teknik dan Ilmu Komputer, Universitas Indraprasta PGRI \\ Jalan Raya Tengah No 80, Kelurahan Gedong, Pasar Rebo, Jakarta Timur \\ adhesrisason08@gmail.com ${ }^{1}$, rahman.abdillah@unindra.ac.id ${ }^{2}$, valentino_na70@yahoo.com ${ }^{3}$
}

\begin{abstract}
Abstrak
Tujuan penelitian ini adalah untuk merancang aplikasi penjualan donat yang merupakan pengembangan dalam hal pelayanan pada perusahaan King Alianz Donuts. Peneliti juga melakukan referensi dan berbagai diskusi serta berbagai media yang memuat informasi mengenai segala sesuatu yang menyangkut informasi dan yang dibutuhkan untuk memecahkan masalah yang ada. Metode yang digunakan dalam penelitian adalah grounded (grounded research). Metode penelitian ini termasuk dalam metode penelitian kualitatif yang menggunakan sejumlah prosedur sistematis yang diarahkan untuk mengembangkan teori berorientasi pada tindakan, interaksi atau proses dengan berlandasan data yang diperoleh dari penelitian. Hasil penelitian ini adalah aplikasi yang dapat membantu memenuhi kebutuhan akan suatu proses penyimpanan data-data pesanan pada perusahaan King Alianz Donuts serta dapat membuat sistem yang lebih baik.
\end{abstract}

Kata Kunci: Perancangan, Sistem Informasi, Penjualan, Java.

\begin{abstract}
The purpose of this research is to design a doughnut sales application which is a development in terms of service at the King Alianz. Donuts Company. Researchers also conducted references and discussions and various media that contained information on everything that pertains to information and needed to solve the problem. The method used in research is grounded research. This method of research is included in qualitative research methods that use a number of systematic procedures directed to develop action-oriented theories, interactions or processes with a foundation of data derived from research. The results of this research an application that can help fulfill the need for a data storage process of order in the company King Alianz Donuts and can make a better system.
\end{abstract}

Keyword: Design, Information Systems, Sales, Java.

\section{PENDAHULUAN}

Seiring berkembangnya teknologi informasi terutama dalam persaingan usaha diberbagai bidang pada era globalisasi seperti sekarang ini sangatlah ketat,serta menuntut pelayanan terbaik oleh perusahaan kepada konsumen. Untuk memberikan pelayanan terbaik kepada konsumen salah satunya yaitu dengan penyediaan informasi yang cepat dan akurat, hal ini dapat dilakukan melalui pemanfaatan penerapan teknologi sistem informasi pada perusahaan. Sistem informasi adalah suatu sistem didalam suatu organisasi yang mempertemukan kebutuhan pengolahan transaksi harian yang mendukung fungsi operasi organisasi yang bersifat manajerial dengan kegiatan strategi dari suatu organisasi untuk dapat menyediakan laporan-laporan yang diperlukan oleh pihak luar tertentu (Sutabri, 2012).

Setelah mengamati dan menganalisa sistem yang berjalan pada PT. King Alianz Donuts, peneliti menemukan beberapa permasalahan yang dapat mempengaruhi kinerja terhadap sistem yang ada. Adapun beberapa masalah yang dihadapi dalam sistem saat ini adalah proses pencatatan data dan transaksi penjualan masih dilakukan dengan cara pencatatan dibuku pencatatan, sehingga sering terjadi kesalahan data ataupun tidak tercatatnya data oleh staff, selain itu sering terjadi kerusakan pada buka data tersebut sehingga menyebabkan kehilangan data yang berakibat kesulitan untuk membuat laporan yang akurat. Berdasarkan permasalahan diatas maka tujuan dari penelitian ini adalah membuat perancangan sistem informasi penjualan yang terkomputerisasi untuk memudahkan dalam melakukan transaksi serta mengatasi kesulitan dalam mengontrol stok donat. Manfaat dari penelitian ini adalah penelitian ini diharapkan menjadi referensi pada penelitian selanjutnya dan mengembangkan kemampuan, keterampilan serta ilmu pengetahuan guna memperoleh gambaran yang baik untuk membuka wawasan tentang peranan Komputer. 


\section{PENELITIAN RELEVAN}

Penelitian yang dilakukan oleh (Setyaningsih, 2012) yang berjudul Perancangan Sistem Informasi Penjualan dan Pengadaan Obat di Apotek Kondang Waras Depok. Dengan hasil data yang dikumpulkan dapat disimpulkan sistem yang diusulkan ini menyimpan semua data yang berhubungan dengan proses penjualan dan pengadaan obat ke dalam database sehingga memungkinkan untuk pegawai dalam memperoleh arsip yang telah lama disimpan. Selanjutnya adalah Penelitian oleh Nurul Fitri Hasanah Universitas Negeri Yogyakarta "Perancangan Sistem Akuntansi Penjualan Tunai Terkomputerisasi Pada Apotek Gedong Kuning" 2012.Penelitian ini bertujuan untuk mengetahui sistem akuntansi penjualan tunai yang telah diterapkan Apotek Gedong Kuning dengan menggunakan tiga pemodelan meliputi pemodelan database yang terdiri dari tabel login, tabel input, tabel karyawan, tabel pemasok, tabel barang, tabel jenis, tabel kategori, tabel penjualan dan tabel penjualan detail.

\section{METODE PENELITIAN}

Metode penelitian adalah suatu cara ilmiah untuk mendapatkan data dengan tujuan kegunaan tertentu (Darmadi, 2013)._Metode yang digunakan dalam penelitian adalah grounded (grounded research). Metode ini termasuk dalam metode penelitian kualitatif yang menggunakan sejumlah prosedur sistematis yang diarahkan untuk mengembangkan teori berorientasi pada tondakan,interaksi atau proses dengan berlandasan data yang diproleh dari kancah penelitian. Dengan metode ini diharapkan dapat mengetahui perbandingan antara data atau fakta dilapangan dengan teori-teori yang ada terhadap proses yang ada sehingga mempermudah penulis dalam membuat aplikasi penjualan bagi perusahaan. Peneliti melakukan metode pemngumpulan data untuk mendapatkan suatu data yang cukup dengan cara pengumpulan bahan keterangan dan data yang berhubungan dengan judul penelitian ini,sehingga tidak menyimpang dari pokok masalah yang ada. Wawancara yaitu melakukan pengumpulan data dengan cara Tanya jawab kepada staff perusahaan pada Pt King Alianz.Dokumentasi yaitu melakukan dokumentasi data agar informasi yang belum didapatkan bisa terpenuhi.Observasi yaitu metode yang dilakukan dengan cara pengamatan langsung dan praktek langsung untuk mendapatkan suatu data.Studi pustaka studi ini dilakukan dengan mempelajari beberapa buku diperpustakaan yang penulis jadi kan referensi dalam penulisan.

Metode pengembangan sistem yang digunakan adalah metode Grounded Research, dengan tahapan sebagai berikut:

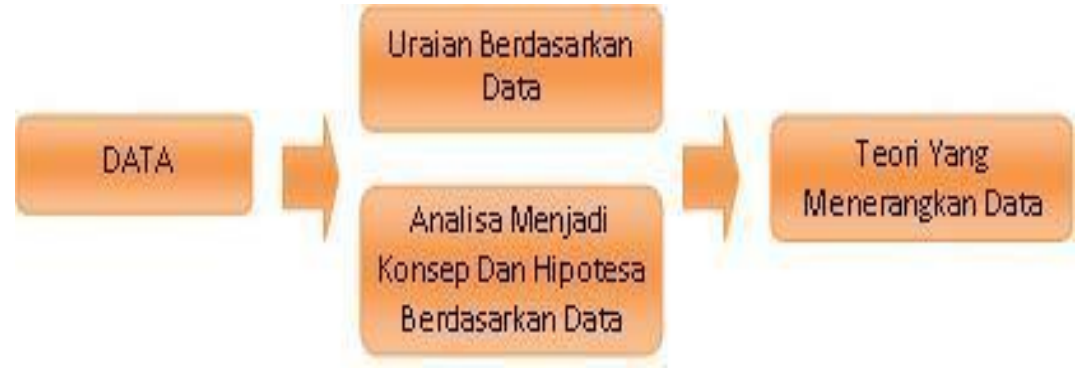

Gambar 1 Metode Grounded Research

\section{HASIL DAN PEMBAHASAN}

Berikut adalah hasil analisis,perancangan, dan keluaran dari penelitian Perancangan Sistem Informasi Penjualan Donat Pada PT King Alianz Donuts di Kranggan,Bogor. 


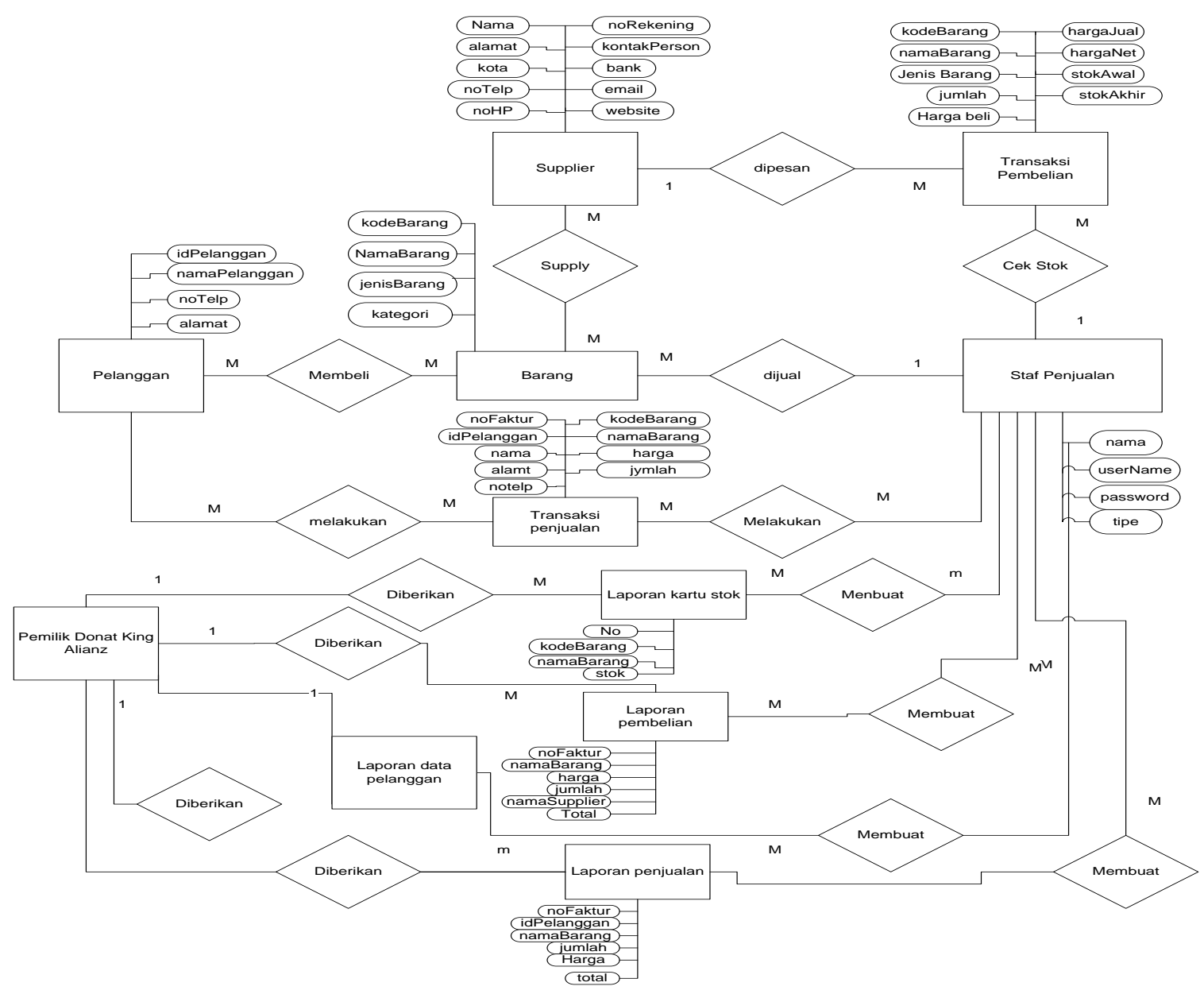

Gambar 2. Entity Relationship Diagram

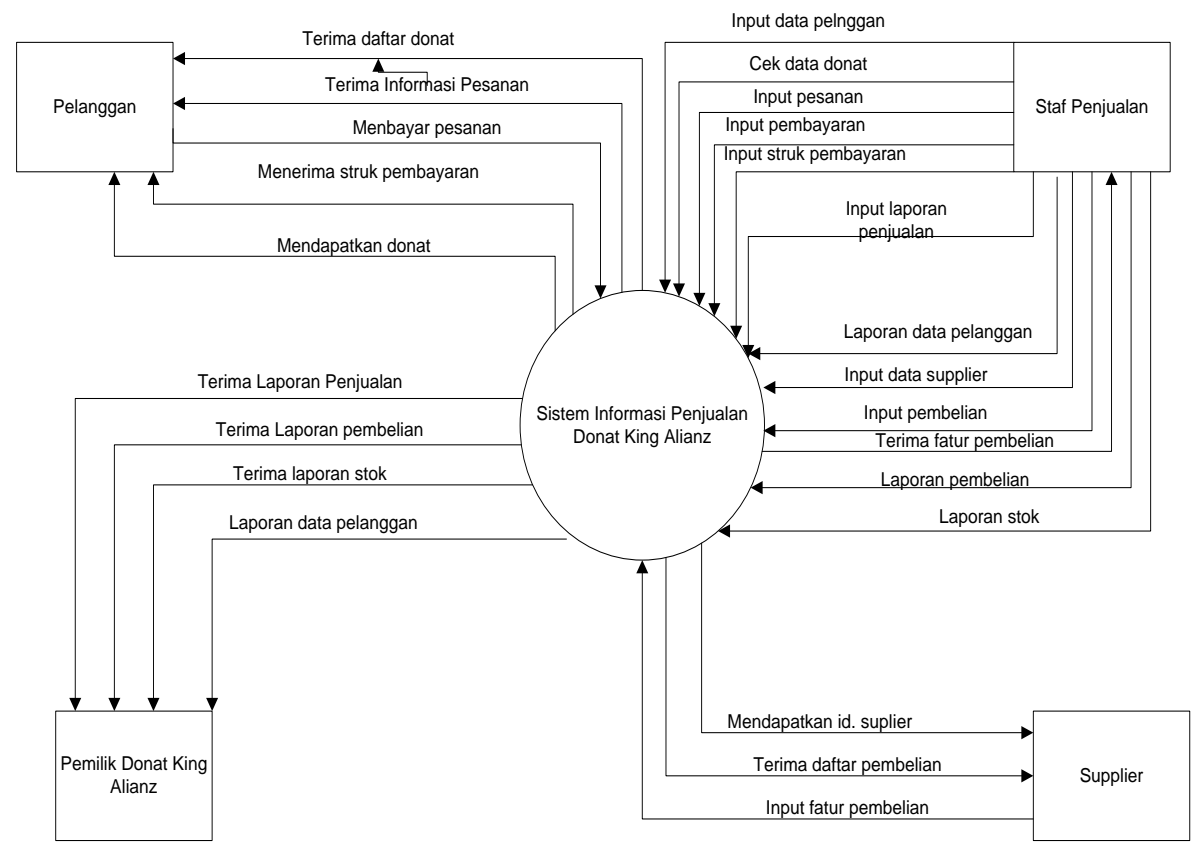

Gambar 3. Diagram Konteks 
Staff bisa melakukan keluar aplikasi untuk kembali kemenu masuk yang bertujuan untuk masuk dengan hak akses lainnya.Staff juga dapat melakukan tutup aplikasi secara menyeluruh.Staff akan mengimput data pelanggan jika ada pelanggan baru,dan staff akan mengimput data pelanggan kedalam database. Staff membuat laporan yang akan dicetak kemudian diberkan kepada pemilik perusahaan.Baik itu laporan data pelanggan,stok,penjualan dan transaksi pengadaan barang. Selain itu juga staff akan mencetak struk penjualan yang akan diberikan ke pelanggan.Kemudian staff akan mengecek seluruh data dalam database yang akan diberikan kepada pimpinan perusahaan disetiap akhir minggu. dan PT Alianz Donutz memiliki aturan-aturan bisnis, di antaranya adalah pemilik akan melakukan penginputan baru untuk data user dan data pegawai ke dalam database. Selanjutnya untuk data pelangggan dan data stok donat akan di input oleh operator. Operator akan mengecek ketersediaan donat saat ada pelanggan yang membeli donat. Pelanggan menanyakan dan memilih donat sesuai yang ingin dibeli kepada operator. Setelah itu operator melakukan penginputan data penjualan ke dalam database. Pelanggan selanjutnya melakukan proses pembayaran donat yang harus dibayar sesuai dengan harga yang telah ditentukan. Setelah itu operator melakukan cetak struk penjualan untuk diberikan kepada pelanggan. Operator melihat seluruh data dalam database yang akan dibuatkan laporan di setiap akhir bulan untuk diserahkan kepada pemilik.

\section{Tampilan Aplikasi}

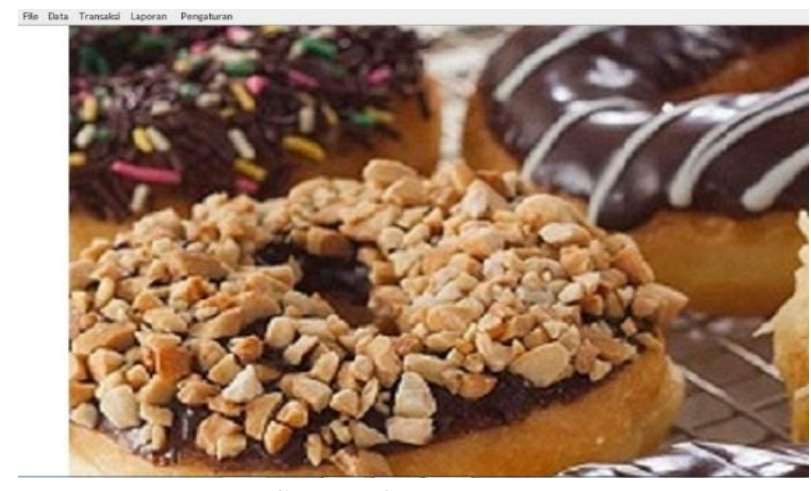

Gambar 4. Form Menu Utama

form menu utama: tampilan ini menampilkan menu pada aplikasi

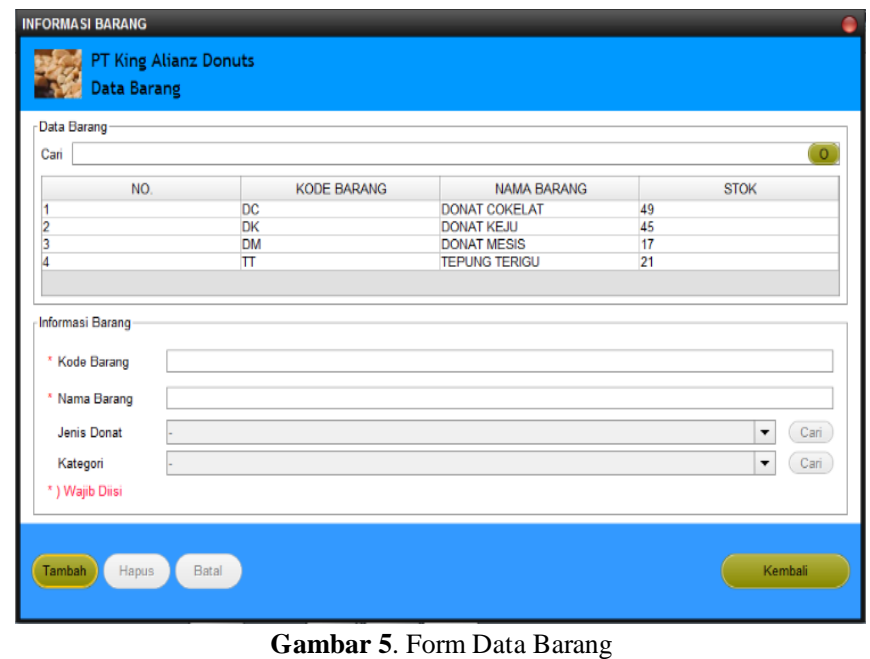

form data barang: menampilkan data barang pada aplikasi 


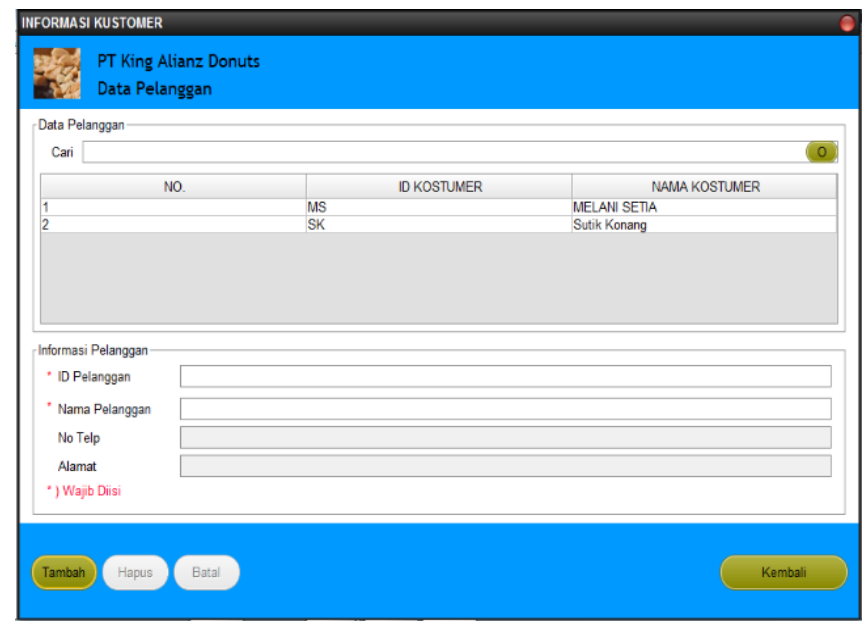

Gambar 6. Form Data Pelanggan

form data barang: menampilkan data pelanggan pada aplikasi

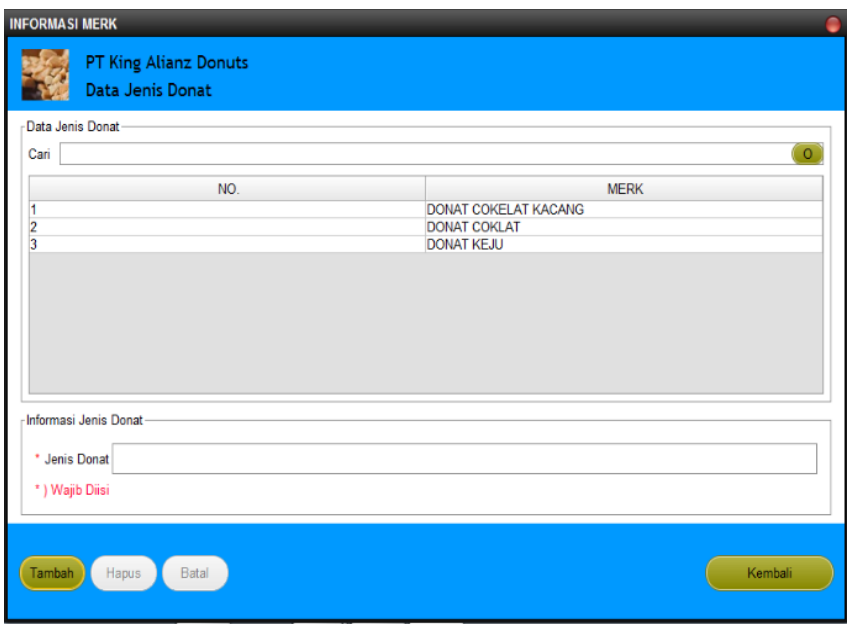

Gambar 7. Form Data Pelanggan

form data barang : menampilkan jenis donat pada aplikasi

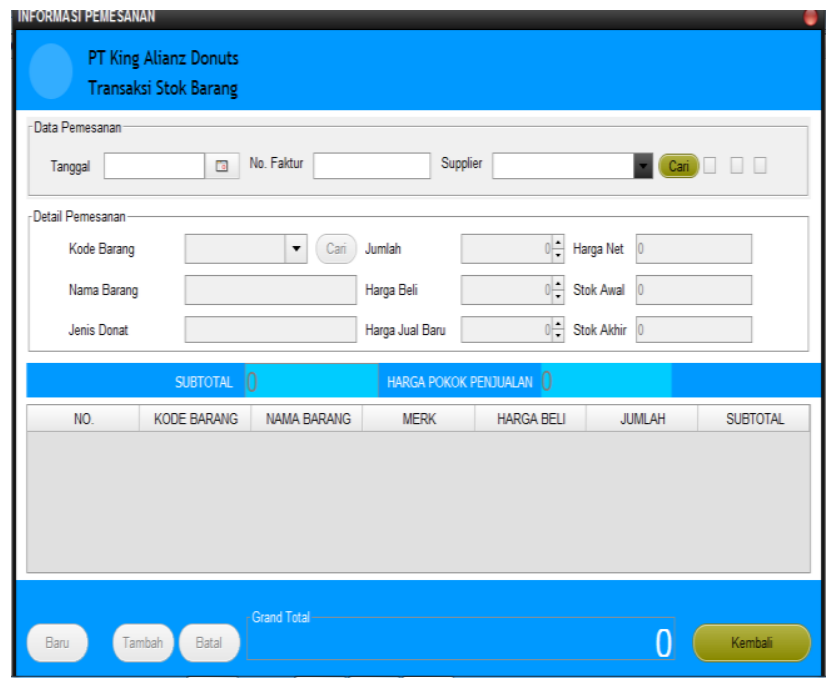

Gambar 8. Form Stok Barang

form transaksi stok donat : menampilkan jumlah stok donat pada aplikasi. 


\section{SIMPULAN}

Dengan adanya sistem informasi penjualan donat, maka masalah pengendalian stok donat dan varian rasa yang ada di pabrik bisa diatasi, karena segala bentuk proses transaksi dihubungkan dengan database yang saling terintegrasi.Dengan adanya sistem informasi penjualan donat, maka pembuatan laporan menjadi lebih mudah karena hanya perlu menggunakan salah satu fasilitas yang ada pada sistem informasi ini.Dengan adanya Perancangan Sistem Informasi Penjualan ini, diharapkan proses pencatatan data transaksi akan lebih efektif dan efisien.Perancangan Sistem Informasi ini akan dapat membantu untuk memperbaiki kesalahan pada penulisan data.

\section{DAFTAR PUSTAKA}

Darmadi, Hamid. (2013). Metode Penelitian Pendidikan dan Sosial. Bandung: Alfabeta.

Krismiaji. (2015). Sistem Informasi Akuntansi (Unit Pener). Yogyakarta.

Setyaningtyas Ashila Sarah. (2012). Perancangan Sistem Informasi Penjualan dan Pengadaan Obat di Apotek Kondang Waras Depok Berbasis Java (Unindra). Jakarta.

Sukamto \& Shalahuddin. (2013). Analisa dan Desain Sistem Informasi (Andi Offset). Yogyakarta.

Sutabri, Tata. (2012). Analisis Sistem Informasi. Yogyakarta:Andi

Yuniar, I. (2015). Basis Data (PT Elex Media Komputindo). Jakarta. 